\title{
KEDOKTERAN EMERGENSI \\ TANTANGAN, HARAPAN, DAN MASA DEPAN
}

\section{(EMERGENCY MEDICINE CHALLENGE, OPPORTUNITY, AND THE FUTURE)}

\author{
Respati Suryanto Dradjat \\ Laboratorium IImu Kedokteran Emergensi Fakultas Kedokteran Universitas Brawijaya
}

\begin{abstract}
The progress of science and technology in globalization era, forcing us to make-up the quality of education and services in the fild of Emergency Medicine (EM). As one of the teaching hospital in Indonesia, Saiful Anwar Hospital - Brawijaya University have developed this education programe. Various challenge, and opportunity have and will be faced to reach the future of Indonesian Medical services to be able to compete in the era of global standard
\end{abstract}

Key words: emergency, education, services

\section{PENDAHULUAN}

Perkembangan ilmu dan teknologi kedokteran dinegara maju telah sedemikian pesat, sehingga untuk mampu bersaing pada era globalisasi dituntut sumber daya manusia yang berkwalitas tinggi, hal ini juga berlaku bagi pelayanan emergensi. Disadari atau tidak, pelayanan emergensi yang diselenggarakan di rumah sakit di Indonesia pada umumnya saat ini tidak dilakukan secara profesional, sehingga morbiditas dan mortalitas menjadi tinggi. Pelatihan jangka pendek (beberapa hari saja) tidak mampu memberikan perubahan kinerja, serta tiadanya dokter yang menekuni profesi kedokteran emergensi (emergency medicine/EM), membuat mutu pelayanan emergensi menjadi rendah (1).

Pada pasar global produk dan jasa pelayanan kesehatan akan bersaing berdasarkan kedalaman pengetahuannya, nilai lebih yang diberikan kepada pelanggannya, serta selalu melakukan perbaikan terus-menerus terhadap sistem dan proses. Hanya dengan begitu kita akan mampu bertahan dan berkembang di pasar global. Era globalisasi menuntut sumber daya manusia berkwalitas tinggi dalam pelayanan kesehatan, khususnya pelayanan emergensi (1). Menurut definisi pelayanan emergensi adalah pelayanan 24 jam dengan standar yang tinggi bagi penderita penyakit akut dan kecelakaan, sehingga tulang punggung pelayanan emergensi adalah dokter dengan pengetahuan, sikap dan ketrampilan yang tinggi dalam mengamalkan ilmu kedokteran emergensi.

$\mathrm{Di}$ Indonesia melalui rumah sakit-rumah sakit pendidikan, ilmu kedokteran emergensi berkembang secara terpisah-pisah melalui berbagai disiplin ilmu kedokteran klinik. Sejauh ini pelayanan emergensi di Indonesia dilaksanakan oleh dokter umum, bahkan yang baru lulus, hanya sebagian kecil dilakukan oleh spesialis, itupun bersifat spesifik sesuai spesialisasinya dan jarang on site 24 jam. Dinegara maju ilmu kedokteran emergensi telah berkembang sebagai disiplin ilmu tersendiri, yaitu sebagai cabang spesialisasi dalam pelayanan

Jurnal Kedokteran Brawijaya, Vol. XX, No.3, Desember 2004

Korespondensi: Respati Suryanto Dradjat; Laboratorium IImu Kedokteran Emergensi FK Unibraw /RSU Dr. Saiful Anwar Malang, Jl. Veteran, Malang 65145. Telp. 0341-580993; Fax.0341-564755 kesehatan dibidang emergensi. IImu kedokteran emergensi mecakup traumatologi, kegawatan jantung, kegawatan pediatri, toksikologi, prahospital dan penanggulangan bencana. Kedokteran emergensi bukan saingan cabang ilmu kedokteran lain, tetapi merupakan jembatan antara masyarakat dengan para spesialis yang akan melakukan terapi definitif (2). Berkembangnya ilmu kedokteran emergensi akan berdampak meningkatan mutu pendidikan dan pelayanan kesehatan di Indonesia, sehingga dapat tercapai pelayanan emergensi yang optimal dan efisien, dan tercapai tujuan untuk menurunkan mortalitas dan morbiditas/kecacatan.

Ruang lingkup kedokteran emergensi mencakup hampir seluruh disiplin ilmu kedokteran, mencakup trauma dan non trauma, bedah dan non bedah, mulai dari multitrauma, pnemonia, gawat jantung hingga kegawatan psikiatri (2). Trauma di wilayah Malang dan sekitarnya mencapai 40,7 \% dari seluruh kasus emergensi dengan angka kematian 1-3\%., dan non trauma $59,3 \%$ dengan kematian kurang dari $1 \%$. Angka kematian ini sebagian besar tergolong preventable death yang seharusnya masih dapat diselamatkan. Penata laksanaan awal trauma dan non trauma membutuhkan ketrampilan dan sarana yang sama, berupa pelayanan emergensi yang mengutamakan life saving, tindakan selanjutnya berupa terapi difinitif dikerjakan oleh bidang spesialisasi masing-masing (1).

RSU Dr Saiful Anwar merupakan RS tipe B pendidikan dari Universitas Brawijaya, melayani penderita emergensi 26.000/tahun dari tahun ke tahun cenderung meningkat. Mempunyai fasilitas kamar operasi emergensi, ICU/ICCU, Laboratorium klinik dan sarana radiologi lengkap, serta didukung oleh tersedianya spesialis cabang ilmu yang terkait. Pendidikan emergensi memungkinkan untuk diselenggarakan melalui integrasi berbagai disiplin ilmu dan pengorganisasian seluruh sarana dan prasarana yang ada, sehingga tercapai pelayanan bebas hambatan untuk menurunkan angka kematian dan kesakitan penderita emergensi. Pendidikan kedokteran emergensi (EM) akan memperbaiki pelayanan, dengan meningkatkan standar pelayanan di rumah sakit maupun pelayanan pra rumah sakit.

Mengembangkan pendidikan dokter spesialis EM mempunyai peluang yang sangat besar, karena untuk memenuhi 
kebutuhan di dalam negeri dan dinegara lain masih sangat terbuka. Di negara2 Asia hanya beberapa negara saja yang telah mengembangkan pendidikan EM (1). Karena peluang yang masih terbuka dan tuntutan akan pelayanan kesehatan berstandar global, maka besar kemungkinan dokter asing akan memanfaatkan kesempatan ini untuk bekerja di negara kita pada rumah sakit-rumah sakit internasional. Setiap tahun Fakultas2 Kedokteran baik negeri maupun swasta yang semakin banyak jumlahnya dan meluluskan lebih banyak dokter baru. Program studi EM akan memberikan kesempatan kepada mereka untuk meningkatkan ilmu pengetahuan dan teknologi, untuk memanfaatkan lapangan kerja yang masih sangat terbuka. Kebutuhan tenaga dokter spesialis EM masih sulit dipenuhi karena sedikitnya pusat pendidikan yang menyelenggarakan program studi ini, sehingga peningkatan jumlah lulusan masih sangat sedikit.

\section{BATASAN}

IImu kedokteran emergensi merupakan cabang ilmu kedokteran yang mempelajari hal yang berkaitan dengan evaluasi, pengelolaan, pengobatan dan pencegahan penyakit yang terjadi secara tiba-tiba dan kecelakaan. IImu Kedokteran emergensi menjembatani antara masyarakat dengan pelayanan medik definitif (3).

Tujuan pendidikan adalah menghasilkan lulusan dengan kemampuan:

1. Mempunyai pengetahuan, pengalaman, ketrampilan dan wawasan yang luas untuk memecahkan masalah emergensi secara ilmiah dan dapat mengamalkan ilmu kedokteran emergensi kepada masyarakat sesuai dengan bidang keahliannya secara optimal.

2. Peka terhadap perilaku, etika, lingkungan sosial, dan organisasi pelayanan emergensi.

3. Mempunyai tanggung jawab, perhatian, menghormati hak dan kewajiban penderita, melaksanakan secara profesional dan penuh rasa tanggung jawab dalam mengamalkan ilmu kedokteran.

4. Mempunyai pengetahuan dan ketrampilan untuk memimpin, merencanakan, melaksanakan, pendidikan dan pengembangan ilmu secara mandiri ke tingkat akademik yang lebih tinggi.

5. Mampu mengikuti dan lulus ujian spesialis emergensi dengan standar global

6. Mampu mengembangkan diri, membangun habitat untuk perkembangan pendidikan, karier, akademik, pelayanan dan subspesialisasi sesuai dengan etika keilmuan dan etika profesi.
Kedokteran emergensi mempunyai ruang lingkup dan lingkungan kerja yang khas, karena peran waktu dan tekanan volume pekerjaan, untuk menghadapi kondisi pasien yang bervariasi, terbatasnya informasi, keterbatasan terapi dan keharusan untuk segera membuat disposisi. Sehingga algoritme emergensi management adalah; pemeriksaan fisik, pemeriksaaan penunjang, anamnesa dan disposisi. Spesialis emergensi akan berada ditempat pelayanan penderita emergensi, mengisi kesenjangan antara komunitas dengan pelayanan spesialistis. Sehingga tercapai efisiensi dalam penggunaan sumberdaya, mengurangi kesalahan, keterlambatan dan tuntutan konsumen. Spesialis emergensi /emergency physician mampu membuat diagnosis yang akurat, memberikan terapi segera, dan merujuk pasien dengan diagnosis yang jelas serta penatalaksanaan yang tepat sebelum pasien memperoleh pengobatan definitif dari spesialis lain. Evaluasi kinerja dilakukan melalui indikator mutu pelayanan emergensi berupa; waiting times, preventable death, time taken to give vital treatment, dan time to emergency operation $(3,4)$.

Sebagai disiplin ilmu kedokteran yang relatif baru, kedokteran emergensi (EM) telah berkembang pesat di Asia. Di negara tetangga, Singapore, Malaysia, Taiwan, Hongkong, Iran dan Israel telah berdiri sebagai spesialisasi baru. Asian Society of Emergency Medicine telah didirikan, melalui konggres yang pertamanya pada tahun 1998 di Singapura. Di Amerika Serikat pada tahun 1979 EM telah diakui sebagai spesialisasi yang ke 23 (1). Dinegara kita terdapat latar belakang budaya, standar kehidupan, dan keadaan sosial ekonomi yang berbeda dengan negara lain. Walaupun demikian kebutuhan pelayanan EM sudah menjadi tuntutan masyarakat. Menjamurnya pelayanan medis 24 jam, berkembangnya pelayanan emergensi di rumah sakit, dan untuk mengembangkan pelayanan prahospital, memerlukan tenaga medis profesional dibidang kedokteran emergensi. Bencana yang sering terjadi di Indonesia, bencana alam maupun buatan manusia, memerlukan dokter-dokter EM yang mampu bekerja di bidang medik maupun manajerial. Tanpa jaminan tersedianya pelayanan emergensi yang bermutu, dan terselenggara dengan baik di rumah sakit-rumah sakit rujukan akan mengurangi kepercayaan turis asing untuk menjadikan negara kita sebagai tujuan wisata.

\section{PENUTUP}

Keberadaan kedokteran emergensi (EM) amat dibutuhkan untuk menyongsong masa depan pelayanan dan pendidikan kedokteran di Indonesia. Pengembangan EM tidak dapat mencontoh apa yang dilakukan di-negara Eropah atau Amerika, karena lingkungan Asia terutama Indonesia memiliki kondisi yang berbeda, dari segi ekonomi dan sosial-budaya.

\section{DAFTAR KEPUSTAKAAN}

1. Dradjat RS. Development of Emergency Medicine in Malang-Indonesia, Proceeding $2^{\text {nd }}$ Asian Congres of Emergency Medicine, Taipei. 2001.

2. Fulde GWO. Post Graduate Training for Emergency Physician. Seminar Pendidikan Dokter Emergensi, Yogyakarta: FK UGM-RS Dr Sardjito-RS Bethesda; 2002: 8-12

3. Wears RL. The Approach to the Emergency Department Patient, The Clinical Practice of Emergency Medicine. $3^{\text {rd }}$ ed, Philadelphia: Lippincott Williams\& Wilkins; 2001: 1-4.

4. Scottke D. Introduction to the EMS system, First Responder, Your First Response in Emergency Care. $3^{\text {rd }}$ ed, Mississauga: Jones and Barlett; 2001: 4-9. 
52 Jurnal Kedokteran Brawijaya, Vol. XX, No. 3, Desember 2004 